\title{
Keanekaragaman laba-laba pada perkebunan kelapa sawit yang berbatasan dengan hutan
}

\author{
Diversity of spiders in oil palm plantations bordering a forest \\ Ulka Sri Asih ${ }^{1}$, Yaherwandi², Siska Efendi ${ }^{*}$ \\ 'PT. Tolan Tiga Indonesia (SIPEF GROUP) \\ Jalan Imam Bonjol No.9, Medan 20112, Indonesia \\ ${ }^{2}$ Program Studi Proteksi Tanaman, Jurusan Hama dan Penyakit Tumbuhan, \\ Fakultas Pertanian, Universitas Andalas, Limau Manis, Padang 25163, Indonesia \\ ${ }^{3}$ Program Studi Agroekoteknologi, Jurusan Budidaya Perkebunan, Fakultas Pertanian, \\ Kampus III Universitas Andalas Dharmasraya \\ Jalan Lintas Sumatera Km 4 Pulau Punjung, Dharmasraya 27612, Indonesia
}

(diterima Januari 2020, disetujui Maret 2021)

\begin{abstract}
ABSTRAK
Keberadaan hutan disekitar perkebunan kelapa sawit akan mempengaruhi komponen biotik penyusun keanekaragaman di perkebunan kelapa sawit terutama spesies yang memiliki mobilisasi dan daya adaptasi tinggi, seperti laba-laba. Penelitian bertujuan untuk mengidentifikasi laba-laba yang terdapat pada perkebunan kelapa sawit dan menganalisis keanekaragaman dan kemerataan pada beberapa jarak perkebunan kelapa sawit dari hutan. Pengamatan laba-laba dilakukan pada perkebunan kelapa sawit yang berbatas dengan hutan yang terdapat di Nagari Gunung Selasih dan Sungai Kambut, Kecamatan Pulau Punjung, Kabupaten Dharmasraya, Provinsi Sumatera Barat. Pada perkebunan kelapa sawit dibuat garis transek sepanjang $1 \mathrm{~km}$ dari pinggir hutan. Berdasarkan garis tersebut dibuat petak sampel sebanyak 10 petak dengan jarak antar petak, yakni $100 \mathrm{~m}$. Pada petak sampel dilakukan pengamatan laba-laba dengan metode pitfall trap, knockdown, dan hand collecting. Data dianalisis dengan indeks keanekaragaman dan kemerataan Shannon-Wienner. Pada penelitian ini dikoleksi laba-laba sebanyak 68 spesies, 15 famili, dan 414 individu. Indeks keanekaragaman spesies laba-laba tertinggi terdapat pada jarak 100-300 m dari hutan berturut-turut, yakni 3,$06 ; 3,05$; dan 3,11 . Hal yang sama juga untuk indeks kemerataan tertinggi terdapat pada jarak 100-300 m dari hutan berturut-turut, yakni 0,$94 ; 0,94$; dan 0,95 . Secara umum hasil penelitian ini memberikan indikasi keberadaan hutan berbatasan hutan diduga berpengaruh terhadap laba-laba pada perkebunan kelapa sawit.
\end{abstract}

Kata kunci: ekosistem, hama, keanekaragaman, kelimpahan, musuh alami

\begin{abstract}
Oil palm plantations bordering forests were thought to affect the biotic components that make up the diversity of ecosystems, especially species with high mobilization and adaptability, such as spiders. This study aims to identify spiders found in oil palm plantations and analyzing diversity and evenness at various distances of oil palm plantations from the forest. Observations of spiders were carried out on oil palm plantations bordered by forests in Nagari Gunung Selasih and Sungai Kambut, Pulau Punjung District, Dharmasraya Regency, West Sumatra Province. In oil palm plantations, a one $\mathrm{km}$ long transect line was made from the forest edge. In the sample plots, spiders were observed using a pitfall trap, knockdown, and hand collecting. Data were analyzed using the Shannon-Wiener diversity and evenness index. The highest spider species diversity index was found

\footnotetext{
*Penulis korespondensi: Siska Efendi. Program Studi Proteksi Tanaman, Jurusan Hama dan Penyakit Tumbuhan, Fakultas Pertanian, Universitas Andalas, Limau Manis, Padang 25163, Tel: 0751-72701, 72702, Email: siskaefendi@agr.unand.ac.id
} 
at a distance of 100-300 $\mathrm{m}$ from the forest, respectively 3.06, 3.05, and 3.11. The same is true for the highest evenness index at a distance of 100-300 m from the forest, respectively, namely 0.94, 0.94, and 0.95 . In general, the results of this study indicate that the presence of forest bordering the forest is thought to affect spiders in oil palm plantations.

Key words: abundance, diversity, ecosystem, natural enemies, pest

\section{PENDAHULUAN}

Laba-laba merupakan predator terbesar pada ekosistem teresterial. Selain itu, laba-laba juga memiliki beberapa kelebihan dibandingkan dengan predator lain. Menurut Stiling \& Cornelissen (2005) laba-laba adalah predator generalis dan lebih efisien untuk pengendalian hama daripada predator spesialis lainnya. Sebagian besar mangsa laba-laba adalah serangga dari Ordo Diptera, Colembolla, Coleoptera, Orthoptera, Lepidoptera, Hemiptera, Trysanoptera, Hymenoptera, dan kelompok laba-laba sendiri serta artropoda lain (Foelix 2011). Laba-laba predator aktif siang dan malam hari dengan mobilitas yang tinggi sehingga aktifitas pemangsaan dapat terjadi pada serangga hama yang bersifat diurnal atau nokturnal.

Laba-laba tergolong cepat untuk beradaptasi dengan perubahan habitat dan ketersediaan mangsa sehingga pada saat kelimpahan mangsa tinggi dan lingkungan sesuai maka pertumbuhan laba-laba akan lebih cepat sehingga populasi meningkat drastis. Iida \& Fujisaki (2007) melaporkan bahwa laba-laba memiliki penyebaran yang luas menempati semua relung yang terdapat pada berbagai jenis habitat, seperti hutan primer, hutan sekunder, padang rumput (Chen \& Tso 2004; Whitmore et al. 2002), hutan tanaman industri (Merwe et al. 1996), lahan pertanian (Downie et al. 1997), perkebunan (Rendón et al. 2006), lahan buah-buahan (Costello \& Daane 1998), lahan tanaman pangan (Thomas \& Jepson 1997), persawahan (Karenina et al. 2019) sampai ke pemukiman (Shochat \& Stefanov 2004). Labalaba mampu berpindah dari satu habitat ke habitat lainnya apabila mengalami gangguan (Öberg et al. 2008).

Habitat laba-laba yang rentan dengan gangguan adalah hutan, padahal ekosistem tersebut memiliki keanekaragaman tinggi. Ekspansi perkebunan kelapa sawit adalah salah satu bentuk gangguan tersebut karena sebagian besar lahan kelapa sawit di dunia dilakukan dengan mengkonversi hutan. Dilaporkan Vijay et al. (2016) bahwa 45\% perkebunan kelapa sawit di Asia Tenggara dan $30 \%$ pada beberapa negara di Amerika Selatan berasal hutan. Ditambahkan Pirker et al. (2016) bahwa ekspansi perkebunan kelapa sawit dengan mengorbankan hutan tropis terutama terjadi di Malaysia dan Indonesia. Hampir 50\% perkebunan kelapa sawit di dua negara tersebut berasal dari hutan (Koh \& Wilcove 2008). Laba-laba dapat mencerminkan perubahan struktur trofik dalam ekosistem yang dilakukan manusia (Shochat \& Stefanov 2004). Hal yang sama juga dilaporkan Potapov et al. (2020) bahwa kepadatan dan keragaman komunitas laba-laba berkaitan erat dengan struktur kompleksitas lingkungan. Hal tersebut dibuktikan Bultman \& Uetz (1982) bahwa manipulasi yang dilakukan pada serasah di hutan berpengaruh terhadap laba-laba terutama laba-laba pembuat jaring.

Perkebunan kelapa sawit adalah agroekosistem hasil manipulasi manusia yang selama ini diduga menjadi penyebab hilangnya keanekaragaman hayati termasuk laba-laba. Hal ini tidak terlepas dari beberapa aktifitas budi daya kelapa sawit secara langsung merusak habitat berbagai organisme yang terdapat di dalamnya, seperti persiapan lahan dengan sistem tebang bakar atau penggunaan berbagai alat berat, pola tanam monokultur, dan proses budi daya yang identik dengan penggunaan berbagai jenis agrokimia. Penggunaan varietas quick stater mendorong petani untuk melakukan pemupukan yang intensif agar tanaman cepat berproduksi. Agar produksi tidak berkurang akibat serangan hama dan penyakit maka penggunaan pestisida dijadikan sebagai solusi utama tanpa mempertimbangkan metode pengendalian yang lain. Jika dilihat secara komprehensif aktifitas tersebut sebagian besar hanya dilakukan pada fase tanaman belum menghasilkan (TBM), setelah memasuki fase tanaman menghasilkan (TM) aktifitas tersebut mulai berkurang.

Jika dibandingkan dengan ekosistem pertanian yang lain frekuensi gangguan terhadap habitat 
tergolong rendah. Budi daya kelapa sawit dilakukan pada fase yang cukup lama, yakni 27 sampai 30 tahun. Berikutnya, letak beberapa perkebunan yang berbatasan dengan hutan diduga akan berpengaruh terhadap keanekaragaman labalaba. Hal tersebut tidak terlepas dari tingginya keanekaragaman laba-laba pada ekosistem hutan. Sebelumnya, sudah dilaporkan Elliott (1930) terdapat 90 spesies laba-laba pada hutan di Indiana Selatan. Sorensen (2004) melaporkan terdapat 149 spesies laba-laba di hutan Uzungwa di Tanzania. Di India, dilaporkan Chetia \& Kalita (2012) terdapat 95 spesies laba-laba di hutan Assam, dari 1.520 spesies laba-laba yang dilaporkan terdapat di India. Letak perkebunan kelapa sawit yang berdekatan dengan hutan dapat dioptimalkan karena keanekaragaman laba-laba yang tinggi pada ekosistem tersebut. Kemungkinan terdapat keanekaragaman tinggi pada perkebunan kelapa sawit yang berbatasan langsung atau dekat dengan hutan, kemudian semakin jauh dari hutan maka keanekaragaman tersebut akan berkurang. Hal ini dapat terjadi kemungkinan karena mobilisasi laba-laba dari hutan ke perkebunan kelapa sawit, yang selama ini hutan dianggap sebagai sumber keanekaragaman. Penelitian ini bertujuan untuk mengidentifikasi laba-laba yang terdapat pada perkebunan kelapa sawit, dan mengamati hubungan jarak perkebunan kelapa sawit dari hutan terhadap kelimpahan dan keanekaragaman laba-laba.

\section{BAHAN DAN METODE}

\section{Lokasi penelitian dan penentuan petak sampel}

Penelitian dilaksanakan di perkebunan kelapa sawit yang berbatasan dengan hutan sekunder yang terdapat di Nagari Gunung Selasih (-0.939701 BT 101.524541 LS) dan Sungai Kambut(101³6’31,0”, BT 0058' 59,4” LS), Kecamatan Pulau Punjung, Kabupaten Dharmasraya, Provinsi Sumatera Barat. Umur kelapa sawit di kedua lokasi penelitian berkisar 15 sampai 17 tahun. Lokasi penelitian berada pada ketinggian $118-300 \mathrm{~m}$ dpl. Intensitas cahaya, yakni 558,36 lux; suhu, yakni $34,01{ }^{\circ} \mathrm{C}$; dan kelembaban $66 \%$. Pada masingmasing lokasi ditentukan petak sampel secara acak sistematis pada garis transek (Rodrigues et al. 2015; Baldissera et al. 2008). Panjang transek pada ekositem perkebunan kelapa sawit, yakni $1 \mathrm{~km}$. Pada garis tersebut ditentukan 10 petak sampel dengan jarak antar petak, yakni $100 \mathrm{~m}$. Pada ekositem hutan dibuat 1 petak sampel dengan jarak $100 \mathrm{~m}$ dari pinggir hutan. Ukuran petak sampel adalah $2 \mathrm{~m} \times 2 \mathrm{~m}$.

\section{Pengambilan laba-laba}

Pengambilan laba-laba dilakukan dengan menggunakan tiga metode, yaitu pitfall trap (Shochat \& Stefanov 2004), knockdown (Sorensen 2004), dan hand collecting (Elliott 1930; Sorensen 2004). Pitfall trap atau perangkap jebak adalah perangkap yang dipergunakan untuk mengoleksi laba-laba yang terdapat pada permukaan tanah. Perangkap ini terbuat dari gelas berbahan plastik dengan diameter $8 \mathrm{~cm}$ dan tinggi $11,5 \mathrm{~cm}$. Gelas tersebut ditanam di tanah dengan posisi permukaan sejajar dengan permukaan tanah. Gelas diisi air yang dicampur deterjen sebanyak $50 \mathrm{ml}$ atau $1 / 3$ volume gelas, kemudian dipasang selama 24 jam (Shochat \& Stefanov 2004). Metode knockdown dilakukan dengan menyemprotkan insektisida berbahan aktif sipermetrin $250 \mathrm{~g} / 1 \mathrm{ke}$ tanaman kelapa sawit dan gulma yang terdapat di dalam petak sampel. Aplikasi menggunakan hand sprayer volume 151 dengan konsentrasi $2 \mathrm{ml} / \mathrm{l}$. Kain kasa dibentangkan di bawah tanaman kelapa sawit yang disemprot dalam petak sampel. Kain putih tersebut digunakan untuk menampung laba-laba yang mati kemudian jatuh dari pohon setelah penyemprotan (Argañaraz et al. 2017). Beberapa spesies laba-laba pembuat jaring yang mati tidak jatuh ke permukaan tanah, akan tetapi menggantung dengan jaring pada kanopi, untuk itu dilakukan pengguncangan tanaman sampel setelah dilakukan penyemprotan. Metode pengambilan sampel secara langsung menggunakan tangan atau bantuan kuas. Beberapa bentuk koleksi langsung antara lain menundukkan cabang dan pohon kecil, menyaring daun, humus, dan tanah lapisan atas (Potapov et al. 2020). Koleksi langsung juga dilakukan dengan mengupas kulit kayu dan pohon mati, tumpukan kayu dan tunggul sisa pembersihan lahan (Cardoso et al. 2011).

\section{Identifikasi laba-laba}

Identifikasi dilakukan melalui dua tahap, tahap pertama dengan mengelompokkan spesimen berdasarkan adanya persamaan sifat morfologi 
yang dapat diamati secara makroskopis, dan tahap kedua melakukan identifikasi secara mikroskopis menggunakan mikroskop binokuler di laboratorium. Sebagian besar laba-laba yang dikoleksi adalah stadium imago untuk memudahkan proses identifikasi. Laba-laba diidentifikasi sampai pada tingkat spesies yang mengacu pada literatur Gutierrez et al. (2019); Stenchly (2011); Maddison (2015); Prószynski (2016); Metzner (2018); Rollard \& Wesolowska (2002); Prószynski (2017); Bee et al. (2017), dan Whyte \& Anderson (2017).

\section{Analisis data}

Keanekaragaman spesies laba-laba dianalisis menggunakan indeks keanekaragaman dan kemerataan Shannon-Wienner. Untuk melihat hubungan jarak perkebunan kelapa sawit dari hutan terhadap keanekaragaman laba-laba dilakukan dengan analisis regresi. Data dianalisis dengan aplikasi Primer Versi 5 for Windows.

\section{HASIL}

\section{Keanekaragaman dan kelimpahan laba-laba pada perkebunan kelapa sawit yang berbatasan dengan hutan}

Pada perkebunan kelapa sawit berbatasan dengan hutan, laba-laba dikoleksi sebanyak 68 spesies, 15 famili, dan 414 individu (Tabel 1). Spesies laba-laba dengan kelimpahan tertinggi adalah Argiope sp., Oxyopes javanus Thorell, Leucage sp., Misumenops sp., dan Pardosa sp. (Tabel 2). Salticidae, Araneidae, dan Thomisidae adalah famili dengan jumlah spesies tertinggi. Famili Salticidae terdapat 29 spesies, jumlah tersebut sangat mencolok dibandingkan dengan famili yang lain (Tabel 3). Komposisi laba-laba berdasarkan jarak dari hutan menunjukkan bahwa jumlah famili dan individu laba-laba terbanyak terdapat pada jarak $0 \mathrm{~m}$, yakni 13 famili dan 58 individu. Selain itu, semakin jauh dari hutan maka jumlah individu semakin berkurang, akan tetapi pola tersebut hanya terlihat konsisten pada jarak 0-400 m, dan jumlah individu kembali berkurang drastis pada jarak $1000 \mathrm{~m}$ dari hutan. Hal menarik yang ditemukan pada penelitian ini adalah jumlah spesies laba-laba terbanyak terdapat pada jarak 200 dan $300 \mathrm{~m}$ dari hutan, yakni 26 spesies (Tabel 1).

Hasil analisis keanekaragaman laba-laba tidak konsisten dengan jumlah individu dan famili. Data sebelumnya menunjukkan bahwa jumlah individu dan famili semakin berkurang dengan semakin jauhnya jarak kebun kelapa sawit dari hutan, hal tersebut terdapat pada jarak 0-400 m dari hutan. Hal sebaliknya keanekaragaman laba-laba tertinggi terdapat pada jarak $300 \mathrm{~m}$ dari hutan dan indeks keanekaragaman terendah terdapat pada jarak $1.000 \mathrm{~m}$ dari hutan. Data ini memberikan indikasi bahwa semakin jauh dari hutan maka keanekaragaman laba-laba semakin berkurang. Indeks kemerataan spesies tertinggi terdapat pada jarak $300 \mathrm{~m}$ dari hutan (Tabel 4). Hanya saja kalau dilihat secara keseluruhan semua nilai indeks kemerataan pada beberapa jarak dari hutan, yakni $>0,9$ artinya spesies laba-laba penyusun perkebunan kelapa sawit merata atau tidak ada spesies laba-laba yang mendominasi (Tabel 4).

Tabel 1. Keanekaragaman dan kelimpahan laba-laba pada perkebunan kelapa sawit berdasarkan jarak dari hutan

\begin{tabular}{cccc}
\hline Jarak dari hutan $(\mathrm{m})$ & Jumlah famili & Jumlah spesies & Jumlah individu \\
\hline 0 & 13 & 25 & 58 \\
100 & 8 & 25 & 43 \\
200 & 11 & 26 & 43 \\
300 & 11 & 26 & 42 \\
400 & 6 & 16 & 28 \\
500 & 9 & 19 & 35 \\
700 & 9 & 18 & 37 \\
800 & 9 & 17 & 35 \\
1000 & 8 & 13 & 21 \\
\hline
\end{tabular}


Tabel 2. Jumlah individu beberapa spesies laba-laba pada perkebunan kelapa sawit berdasarkan jarak dari hutan

\begin{tabular}{|c|c|c|c|c|c|c|c|c|c|c|c|}
\hline \multirow{2}{*}{$\begin{array}{l}\text { Famili } \\
\quad \text { Spesies }\end{array}$} & \multicolumn{11}{|c|}{ Jarak perkebunan kelapa sawit dari hutan (m) } \\
\hline & 0 & 100 & 200 & 300 & 400 & 500 & 600 & 700 & 800 & 900 & 1000 \\
\hline \multicolumn{12}{|l|}{ Araneidae } \\
\hline Anepsion sp. & 0 & 0 & 1 & 1 & 0 & 0 & 0 & 0 & 0 & 1 & 0 \\
\hline Argiope sp. & 5 & 1 & 2 & 5 & 4 & 6 & 5 & 5 & 6 & 4 & 1 \\
\hline Deliochus sp. & 0 & 2 & 0 & 0 & 0 & 0 & 0 & 0 & 0 & 1 & 0 \\
\hline Gasteracantha formicata & 0 & 0 & 0 & 0 & 0 & 2 & 1 & 0 & 1 & 0 & 0 \\
\hline Gea sp. & 2 & 0 & 0 & 0 & 0 & 0 & 0 & 0 & 0 & 0 & 0 \\
\hline Neoscona sp. & 0 & 0 & 3 & 1 & 1 & 1 & 0 & 0 & 1 & 0 & 0 \\
\hline Nephila maculata & 1 & 0 & 0 & 0 & 0 & 0 & 0 & 0 & 0 & 0 & 0 \\
\hline \multicolumn{12}{|l|}{ Clubionidae } \\
\hline Clubiona sp. & 3 & 2 & 2 & 1 & 2 & 2 & 0 & 3 & 0 & 2 & 2 \\
\hline Metidia sp. & 0 & 0 & 0 & 0 & 1 & 0 & 0 & 0 & 0 & 0 & 0 \\
\hline \multicolumn{12}{|l|}{ Dictynidae } \\
\hline Dyctina gramic & 5 & 0 & 0 & 0 & 0 & 0 & 0 & 0 & 0 & 0 & 0 \\
\hline Gallieniellidae & 0 & 0 & 1 & 0 & 0 & 0 & 0 & 0 & 1 & 0 & 0 \\
\hline Oreo sp. & 0 & 0 & 1 & 0 & 0 & 0 & 0 & 0 & 1 & 0 & 0 \\
\hline
\end{tabular}

Gnaphosidae

$\begin{array}{llllllllllll}\text { Hersilia sundaica } & 1 & 0 & 0 & 0 & 0 & 0 & 0 & 0 & 0 & 0 & 0 \\ \text { Zelotes latreillei } & 1 & 0 & 0 & 0 & 0 & 0 & 0 & 0 & 0 & 0 & 0\end{array}$

Lycosidae

Hipposa sp.

Pardosa sp.

Pirata sp.

Schizocosa sp.

Oxyopidae

Oxyopes javanus

Oxyopes sp.

Salticidae

Carrhotus sp.

Cosmophasis estrellaensis

Cosmophasis sp.

Cosmophasis trioipina

Epeus edwardsi

Hormochirus brachiatus

Ligura sp.

Phintella sp.

Phintella versicolor

$\begin{array}{lllllllllll}1 & 1 & 0 & 0 & 1 & 0 & 0 & 0 & 1 & 0 & 0 \\ 4 & 1 & 0 & 1 & 6 & 1 & 3 & 0 & 0 & 2 & 3 \\ 1 & 1 & 1 & 2 & 0 & 2 & 1 & 2 & 0 & 0 & 4 \\ 1 & 1 & 4 & 0 & 1 & 3 & 4 & 2 & 4 & 0 & 1\end{array}$

Phintella vitteta

Plexippus calcuttaensis

$\begin{array}{lllllllllll}3 & 2 & 5 & 3 & 1 & 3 & 3 & 6 & 5 & 5 & 2 \\ 0 & 0 & 1 & 2 & 2 & 1 & 1 & 1 & 0 & 0 & 0\end{array}$

Plexippus sp.

Rumburuka laxus

$\begin{array}{lllllllllll}1 & 1 & 0 & 0 & 0 & 0 & 0 & 0 & 0 & 0 & 0\end{array}$

Rumburuka sp.

$\begin{array}{lllllllllll}0 & 0 & 0 & 0 & 0 & 0 & 0 & 0 & 0 & 1 & 0\end{array}$

$\begin{array}{lllllllllll}1 & 1 & 1 & 0 & 1 & 0 & 1 & 0 & 1 & 0 & 0\end{array}$

$\begin{array}{lllllllllll}0 & 1 & 0 & 0 & 0 & 0 & 0 & 0 & 0 & 0 & 0\end{array}$

$\begin{array}{lllllllllll}0 & 0 & 1 & 0 & 0 & 0 & 0 & 0 & 0 & 0 & 0\end{array}$

$\begin{array}{lllllllllll}3 & 1 & 0 & 1 & 0 & 0 & 2 & 0 & 0 & 0 & 0\end{array}$

$\begin{array}{lllllllllll}0 & 0 & 1 & 0 & 0 & 0 & 0 & 0 & 0 & 0 & 0\end{array}$

$\begin{array}{lllllllllll}0 & 2 & 1 & 1 & 0 & 1 & 0 & 1 & 2 & 0 & 0\end{array}$

$\begin{array}{lllllllllll}0 & 0 & 0 & 0 & 0 & 0 & 0 & 1 & 0 & 0 & 0\end{array}$

$\begin{array}{lllllllllll}0 & 0 & 1 & 0 & 0 & 0 & 0 & 0 & 0 & 0 & 0\end{array}$

$\begin{array}{lllllllllll}0 & 1 & 0 & 0 & 0 & 0 & 1 & 0 & 0 & 0 & 0\end{array}$

$\begin{array}{lllllllllll}0 & 0 & 0 & 1 & 0 & 0 & 0 & 1 & 1 & 1 & 1\end{array}$

$\begin{array}{lllllllllll}0 & 0 & 0 & 0 & 0 & 0 & 1 & 0 & 0 & 0 & 0\end{array}$

$\begin{array}{lllllllllll}0 & 0 & 0 & 0 & 0 & 0 & 0 & 0 & 0 & 0 & 1\end{array}$ 
Tabel 2. Jumlah individu beberapa spesies laba-laba pada perkebunan kelapa sawit berdasarkan jarak dari hutan (Lanjutan...)

\begin{tabular}{|c|c|c|c|c|c|c|c|c|c|c|c|}
\hline \multirow{2}{*}{$\begin{array}{l}\text { Famili } \\
\quad \text { Spesies }\end{array}$} & \multicolumn{11}{|c|}{ Jarak perkebunan kelapa sawit dari hutan (m) } \\
\hline & 0 & 100 & 200 & 300 & 400 & 500 & 600 & 700 & 800 & 900 & 1000 \\
\hline Salticus firgatus & 0 & 2 & 1 & 0 & 0 & 0 & 2 & 5 & 3 & 2 & 1 \\
\hline Sidusa gratiosa & 0 & 0 & 0 & 0 & 0 & 0 & 0 & 0 & 0 & 1 & 0 \\
\hline Talavera thorelli & 0 & 2 & 0 & 0 & 1 & 0 & 0 & 0 & 0 & 0 & 0 \\
\hline Tanzania meridionalis & 0 & 0 & 1 & 2 & 0 & 0 & 0 & 0 & 0 & 0 & 0 \\
\hline Thiania bhamoensis & 0 & 0 & 0 & 1 & 0 & 0 & 0 & 0 & 0 & 0 & 0 \\
\hline Thiania gazellae & 0 & 1 & 0 & 1 & 0 & 2 & 1 & 0 & 0 & 0 & 0 \\
\hline Thiania latibela & 0 & 0 & 0 & 1 & 1 & 0 & 0 & 0 & 0 & 0 & 0 \\
\hline Thorelliola ensifera & 0 & 2 & 2 & 1 & 0 & 0 & 0 & 1 & 0 & 2 & 0 \\
\hline Thorelliola joannae & 0 & 1 & 1 & 0 & 1 & 0 & 0 & 0 & 0 & 0 & 0 \\
\hline Thorelliola pallidula & 1 & 3 & 2 & 0 & 0 & 1 & 0 & 2 & 3 & 0 & 0 \\
\hline Thorelliola zabkai & 0 & 1 & 0 & 0 & 0 & 1 & 1 & 0 & 0 & 0 & 0 \\
\hline Thyenula armata & 1 & 0 & 0 & 0 & 0 & 0 & 0 & 0 & 0 & 1 & 0 \\
\hline Thyenula wesolowskae & 0 & 0 & 0 & 0 & 0 & 0 & 0 & 0 & 0 & 2 & 0 \\
\hline Tisaniba mulu & 0 & 1 & 0 & 2 & 0 & 0 & 0 & 1 & 0 & 0 & 0 \\
\hline Truncattus flavus & 0 & 0 & 0 & 0 & 1 & 1 & 0 & 1 & 0 & 1 & 0 \\
\hline Tylogonus auricapillus & 0 & 0 & 0 & 0 & 0 & 0 & 1 & 0 & 0 & 0 & 0 \\
\hline \multicolumn{12}{|l|}{ Scytodidae } \\
\hline Dictis striatipes & 0 & 0 & 1 & 2 & 0 & 0 & 1 & 0 & 0 & 1 & 0 \\
\hline Scytodes pallidus & 1 & 0 & 0 & 0 & 0 & 0 & 0 & 0 & 0 & 0 & 0 \\
\hline Scytodes tardigiade & 0 & 0 & 0 & 0 & 0 & 0 & 0 & 0 & 0 & 1 & 2 \\
\hline Scytodes thoracica & 2 & 0 & 1 & 0 & 0 & 1 & 0 & 0 & 0 & 0 & 0 \\
\hline \multicolumn{12}{|l|}{ Sparassidae } \\
\hline Heteropoda jugulans & 6 & 6 & 1 & 1 & 0 & 1 & 1 & 1 & 0 & 0 & 1 \\
\hline Seramba sp. & 0 & 0 & 0 & 0 & 0 & 1 & 0 & 0 & 0 & 0 & 0 \\
\hline \multicolumn{12}{|l|}{ Tetragnathidae } \\
\hline Leucage sp. & 7 & 3 & 1 & 3 & 0 & 3 & 2 & 1 & 2 & 3 & 1 \\
\hline Pachygnatha sp. & 1 & 0 & 0 & 0 & 0 & 0 & 0 & 0 & 0 & 0 & 0 \\
\hline Theridiidae & 2 & 0 & 0 & 0 & 0 & 0 & 1 & 0 & 0 & 0 & 0 \\
\hline Enoplognatha ovata & 2 & 0 & 0 & 0 & 0 & 0 & 1 & 0 & 0 & 0 & 0 \\
\hline \multicolumn{12}{|l|}{ Thomisidae } \\
\hline Camericus sp. & 0 & 0 & 0 & 1 & 0 & 0 & 0 & 0 & 0 & 0 & 0 \\
\hline Misumenops sp. & 0 & 3 & 5 & 3 & 3 & 2 & 1 & 2 & 1 & 5 & 0 \\
\hline Misumenops vatia & 0 & 0 & 1 & 0 & 0 & 0 & 0 & 0 & 0 & 0 & 0 \\
\hline Strophinae sp. & 0 & 0 & 0 & 0 & 0 & 0 & 0 & 0 & 0 & 1 & 0 \\
\hline Synema globosum clarum & 0 & 0 & 0 & 1 & 0 & 0 & 0 & 0 & 0 & 0 & 0 \\
\hline Tharpyna diademata & 0 & 0 & 0 & 1 & 0 & 0 & 0 & 0 & 0 & 0 & 0 \\
\hline Thomisius sp. & 0 & 0 & 0 & 0 & 1 & 0 & 0 & 0 & 0 & 0 & 0 \\
\hline \multicolumn{12}{|l|}{ Uloboridae } \\
\hline Philoponella sp. & 0 & 0 & 1 & 2 & 0 & 0 & 0 & 0 & 1 & 0 & 0 \\
\hline Uloborus lugubris & 1 & 0 & 0 & 0 & 0 & 0 & 0 & 0 & 1 & 0 & 1 \\
\hline \multicolumn{12}{|l|}{ Zodariidae } \\
\hline Melinella sp. & 3 & 0 & 0 & 1 & 0 & 0 & 1 & 1 & 1 & 0 & 0 \\
\hline
\end{tabular}


Pengaruh jarak dari hutan terhadap keanekaragaman dan kelimpahan laba-laba

Secara keseluruhan terlihat perbedaan kelimpahan populasi laba-laba berdasarkan jarak dari hutan, semakin jauh jarak dari hutan kelimpahan populasi laba-laba berkurang. Pada jarak $0 \mathrm{~m}$ dari hutan terdapat empat famili dengan kelimpahan tertinggi, yaitu Araneidae, Lycosidae, Salticidae, dan Tetragnathidae (Tabel 3). Kelimpahan labalaba dari Famili Salticidae meningkat signifikan pada jarak $100 \mathrm{~m}$, sedangkan tiga famili yang lain berkurang drastis. Secara keseluruhan jumlah individu semua famili laba-laba berkurang secara drastis pada jarak $400 \mathrm{~m}$ dari hutan, tetapi meningkat kembali pada jarak 500 sampai $700 \mathrm{~m}$, terutama pada Famili Lycosidae, Oxyopidae, dan Salticidae (Tabel 3).

Jika dilihat secara keseluruhan, terlihat jumlah individu masing-masing spesies berkurang bersamaan dengan jarak yang semakin jauh dari hutan. Walaupun pengurangan tersebut hanya terlihat pada jarak 0 sampai $400 \mathrm{~m}$. Argiope sp.,
Heteropoda jugulans (L. Koch), Leucage sp. adalah tiga spesies laba-laba yang paling melimpah pada jarak $0 \mathrm{~m}$ dari hutan. Berikutnya, pada jarak $100 \mathrm{~m}$ dari hutan hanya spesies $H$. jugulans yang memiliki kelimpahan tertinggi, dan hampir semua spesies yang ditemukan pada jarak $0 \mathrm{~m}$ dari hutan jumlahnya berkurang secara signifikan. Berikutnya, hal menarik yang dapat dilihat adalah tidak ada spesies laba-laba yang memiliki jumlah individu yang konsisten, baik bertambah karena dekat dengan hutan atau sebaliknya. Argiope sp. yang populasinya berkurang pada jarak $100 \mathrm{~m}$ dari hutan kembali meningkat mulai dari jarak $300 \mathrm{~m}$ sampai $800 \mathrm{~m}$, kemudian mulai berkurang pada jarak 900 dan $1.000 \mathrm{~m}$ dari hutan.

Hasil analisis regresi menunjukkan bahwa jarak perkebunan kelapa sawit dari hutan mempunyai hubungan sangat nyata dengan keanekaragaman $\left(\mathrm{R}^{2}=0,59 ; \mathrm{P}=0,0058\right)$, sedangkan kemerataan mempunyai hubungan nyata $\left(\mathrm{R}^{2}=\right.$ $0,53 ; \mathrm{P}=0,0117)($ Gambar 1).

Tabel 3. Jumlah individu setiap famili laba-laba pada perkebunan kelapa sawit berdasarkan jarak dari hutan

\begin{tabular}{|c|c|c|c|c|c|c|c|c|c|c|c|}
\hline \multirow{2}{*}{ Famili } & \multicolumn{11}{|c|}{ Jarak perkebunan kelapa sawit dari hutan (m) } \\
\hline & 0 & 100 & 200 & 300 & 400 & 500 & 600 & 700 & 800 & 900 & 1000 \\
\hline Araneidae & 8 & 3 & 6 & 7 & 5 & 9 & 6 & 5 & 8 & 6 & 1 \\
\hline Clubionidae & 3 & 2 & 2 & 1 & 3 & 2 & 0 & 3 & 0 & 2 & 2 \\
\hline Dictynidae & 5 & 0 & 0 & 0 & 0 & 0 & 0 & 0 & 0 & 0 & 0 \\
\hline Gallieniellidae & 0 & 0 & 1 & 0 & 0 & 0 & 0 & 0 & 1 & 0 & 0 \\
\hline Gnaphosidae & 2 & 0 & 0 & 0 & 0 & 0 & 0 & 0 & 0 & 0 & 0 \\
\hline Lycosidae & 7 & 4 & 5 & 3 & 8 & 6 & 8 & 4 & 5 & 2 & 8 \\
\hline Oxyopidae & 3 & 2 & 6 & 5 & 3 & 4 & 4 & 7 & 5 & 5 & 2 \\
\hline Salticidae & 7 & 20 & 12 & 11 & 5 & 6 & 10 & 13 & 10 & 11 & 3 \\
\hline Scytodidae & 3 & 0 & 2 & 2 & 0 & 1 & 1 & 0 & 0 & 2 & 2 \\
\hline Sparassidae & 6 & 6 & 1 & 1 & 0 & 2 & 1 & 1 & 0 & 0 & 1 \\
\hline Tetragnathidae & 8 & 3 & 1 & 3 & 0 & 3 & 2 & 1 & 2 & 3 & 1 \\
\hline Theridiidae & 2 & 0 & 0 & 0 & 0 & 0 & 1 & 0 & 0 & 0 & 0 \\
\hline Thomisidae & 0 & 3 & 6 & 6 & 4 & 2 & 1 & 2 & 1 & 6 & 0 \\
\hline Uloboridae & 1 & 0 & 1 & 2 & 0 & 0 & 0 & 0 & 2 & 0 & 1 \\
\hline Zodariidae & 3 & 0 & 0 & 1 & 0 & 0 & 1 & 1 & 1 & 0 & 0 \\
\hline Jumlah individu & 58 & 43 & 43 & 42 & 28 & 35 & 35 & 37 & 35 & 37 & 21 \\
\hline Kekayaan spesies & 25 & 25 & 26 & 26 & 16 & 19 & 21 & 18 & 17 & 19 & 13 \\
\hline Keanekaragaman & 2,97 & 3,06 & 3,05 & 3,11 & 2,53 & 2,77 & 2,86 & 2,65 & 2,59 & 2,75 & 2,43 \\
\hline Kemerataan & 0,94 & 0,94 & 0,94 & 0,95 & 0,90 & 0,92 & 0,93 & 0,91 & 0,91 & 0,92 & 0,90 \\
\hline
\end{tabular}


A

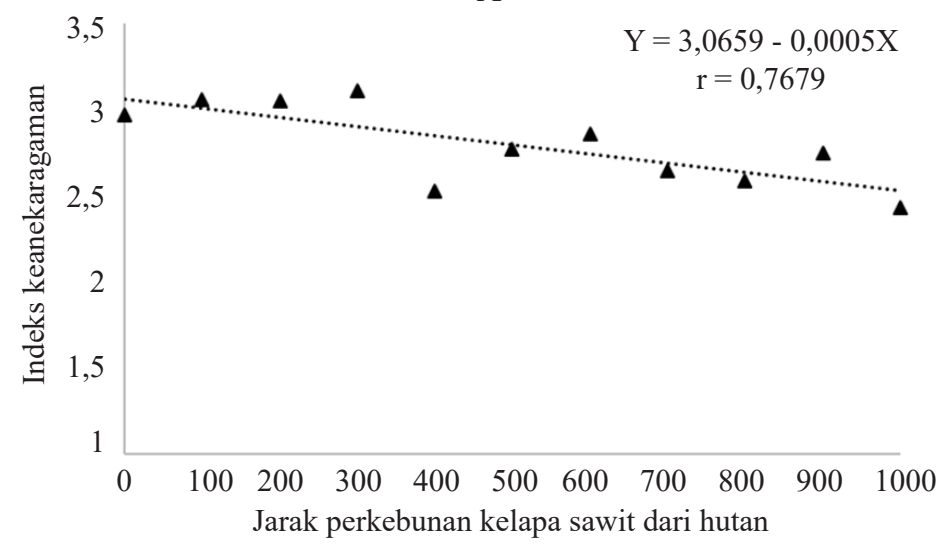

B

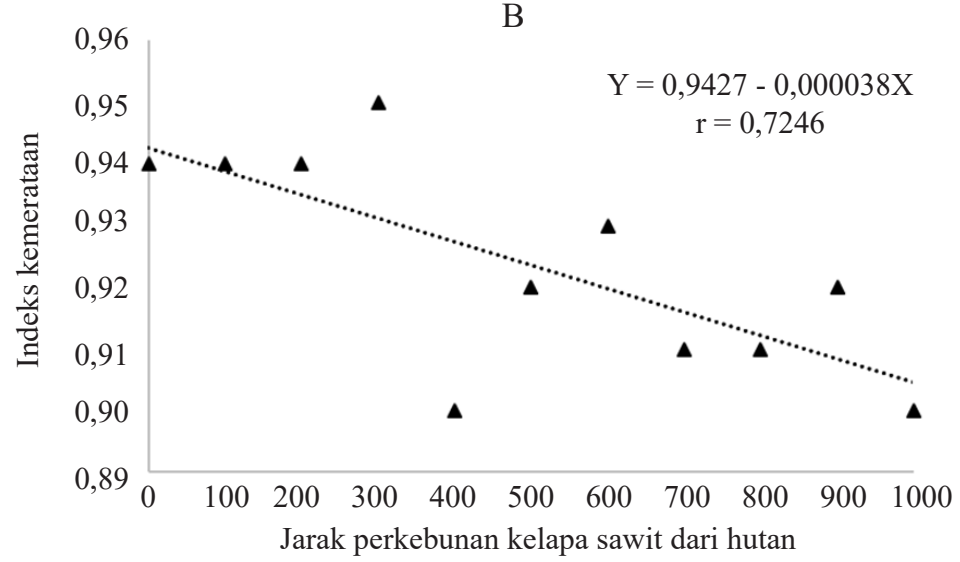

Gambar 1. Hubungan jarak perkebunan kelapa sawit dari hutan terhadap keanekaragaman (A) dan kemerataan (B) spesies laba-laba.

\section{PEMBAHASAN}

Spesies laba-laba yang ditemukan pada perkebunan kelapa sawit yang berbatas dengan hutan tergolong tinggi. Argiope sp. adalah spesies yang melimpah pada perkebunan kelapa sawit. Motta \& Levi (2009) melaporkan terdapat 76 spesies laba-laba dari Genus Argiope dan sebagian besar tersebar luas di kawasan tropis. Tingginya kelimpahan Argiope sp. pada beberapa tipe habitat hutan atau habitat yang terbentuk karena fragmentasi (Das et al. 2018). Beberapa faktor yang diduga mempengaruhi kelimpahan tersebut adalah daya adaptasi tinggi, kisaran mangsa luas, ketersediaan vegetasi alami untuk membuat jaring. Argiope sp. bersifat synanthropic (berhubungan erat dengan manusia) sehingga aktifitas budi daya kelapa sawit tidak mengganggu keberadaan spesies tersebut. Hal yang berbeda dengan $O$. javanus yang memiliki kelimpahan tinggi disebabkan oleh ketersedian mangsa. O. javanus adalah predator polyphagous yang memangsa lebih kurang sembilan spesies arthropoda, dengan mangsa utama adalah serangga dari Ordo Diptera, Hymenoptera, Heteroptera, Orthoptera, dan Lepidoptera (Huseynov 2007). Sebagian besar hama kelapa sawit dari Ordo Lepidoptera dan diduga menjadi mangsa $O$. javanus.

Salticidae adalah famili dengan jumlah spesies terbanyak dari kelas laba-laba. Menurut World Spider Catalog (2019) Salticidae terdiri dari 6.108 spesies dan 636 genus. Sebagian besar spesies tersebut tersebar di kawasan tropis terutama Afrika dan Asia. Pada perkebunan kelapa sawit berbatas hutan ditemukan sebanyak 29 spesies laba-laba dari Famili Salticidae. Famili Salticidae bersifat terestrial dan dikenal dengan sebutan laba-laba pelompat (jumping spiders). Kemampuan tersebut didukung dengan karakteristik laba-laba Salticidae yang paling luar biasa dan menonjol terletak pada ketajaman visual yang berkembang sangat baik, ditandai dengan mata besar yang berbentuk tabung (Hill \& Richman 2009). Serasah pada ekosistem hutan dan perkebunan kelapa sawit mendukung 
kelimpahan Salticidae. Pada perkebunan kelapa sawit pelepah sisa panen dan pruning disusun pada gawangan dan dibiarkan melapuk. Serasah tersebut sudah menumpuk cukup tinggi karena tanaman kelapa sawit pada lokasi penelitian sudah berumur 17 tahun. Menurut Marshall \& Rysptra (1999) bahwa serasah yang semakin tebal akan menyebabkan habitat semakin lembab, tidak hanya itu pada serasah banyak tersedia mangsa, dan serasah juga berfungsi sebagai tempat untuk bersembunyi dan terhindar dari suhu ekstrim. Hal yang sama juga dilaporkan Argañaraz et al. (2017) bahwa spesies yang termasuk Famili Salticidae memiliki hubungan yang sangat erat dengan mikrohabitat, keanekaragaman tanaman, dan mangsa.

Araneidae adalah famili ketiga dengan jumlah spesies terbanyak pada kelas laba-laba. Termasuk ke dalam Famili Araneidae adalah Ecribellate, Entelegyne, laba-laba cakar tiga, dan laba-laba yang memiliki delapan mata dalam dua baris. Keanekaragaman Araneidae pada perkebunan kelapa sawit berhubungan dengan ketersediaan habitat untuk membuat jaring karena laba-laba yang termasuk famili tersebut dikenal dengan pembuat jaring. Keanekaragaman Araneidae yang tinggi pada hutan karena ketersedian pohon dengan berbagai variasi ketinggian untuk membuat jaring. Sebaliknya, pada perkebunan kelapa sawit pepohonan tersebut sudah ditumbangkan pada saat land clearing. Pohon kelapa sawit dapat menjadi habitat alternatif untuk Araneidae karena arsitektur kelapa sawit memungkinkan laba-laba untuk membuat jaring. Batang kelapa sawit dapat mencapai ketinggian maksimum, yakni $15 \mathrm{~m}$. Pada batang tersebut terdapat pelepah sebanyak 48-56 dengan panjang dapat mencapai $4 \mathrm{~m}$ atau tergantung varietas. Pelepah sawit yang saling tumpang tindih dalam satu kebun merupakan penghubung/koridor yang memberikan jalan bagi laba-laba untuk melakukan penyebaran sehingga laba-laba dapat berpindah dari satu habitat ke habitat lain, seperti perkebunan kelapa sawit yang berbatasan langsung atau berdekatan dengan hutan.

Perkebunan kelapa sawit yang berbatasan dengan hutan memiliki jumlah individu dan famili yang tinggi. Araneidae adalah famili labalaba yang memiliki kekayaan spesies tinggi pada perkebunan kelapa sawit yang berbatas dengan hutan. Pada jarak $0 \mathrm{~m}$ dari hutan kelimpahan
Araneidae lebih tinggi dibandingkan dengan famili yang lain. Sebelumnya, hal yang sama juga dilaporkan Baldissera et al (2008) bahwa kelimpahan Araneidae lebih tinggi di dalam dibandingkan dengan pinggir hutan. Kondisi ini berhubungan dengan tipe hutan tempat pengambilan sampel yang merupakan hutan sekunder. Pada pinggir hutan tidak ditumbuhi pohon yang rapat dan pohon yang tumbuh berukuran kecil dengan ketinggian 4-7 meter. Menurut Foelix (2011) tempat pembuatan jaring tidak hanya membutuhkan iklim mikro spesifik, tetapi juga ruang. Pohon yang rapat di dalam hutan akan membuat laba-laba sulit untuk membuat jaring karena menurut Levi (2002) Araneidae terkenal dengan sebutan laba-laba pembuat jaring bola, yang membutuhkan ruang yang besar untuk membuat jaring. Berikutnya, beberapa faktor lingkungan juga akan mempengaruhi laba-laba, terutama angin dan suhu. Angin yang kuat di dalam hutan akan mengakibatkan jaring labalaba rusak (de Souza \& Martins 2004). Suhu yang lebih tinggi di pinggir hutan ikut mempengaruhi kelimpahan Araneidae di perkebunan kelapa sawit yang berbatas hutan. Araneidae cenderung akan beranekaragaman pada daerah dengan temperatur tinggi. Hal yang sama juga dilaporkan Rodrigues et al. (2015) bahwa distribusi temporal dari Araneidae menunjukkan puncak pada musim panas. Akan tetapi, tidak semua famili laba-laba memiliki respons yang sama.

Keanekaragaman laba-laba pada beberapa jarak dari hutan terlihat tidak konsisten. Keanekaragaman laba-laba tinggi pada jarak $0 \mathrm{~m}$, kemudian berkurang sampai jarak $300 \mathrm{~m}$. Setelah itu, pada jarak $500 \mathrm{~m}$ sampai dengan $900 \mathrm{~m}$ keanekaragaman laba-laba kembali meningkat, walapun tidak setinggi pada jarak 0-300 m. Hal tersebut disebabkan laba-laba pada perkebunan kelapa sawit berasal dari sumber yang berbeda. Pada jarak 0-300 m, diduga berasal dari hutan, sedangkan pada jarak 500-900 m terbentuk dari koloni laba-laba yang masih bertahan setelah dilakukan land clearing. Kondisi perkebunan kelapa sawit berdekatan dengan hutan memungkinkan terjadinya mobilisasi dari habitat tersebut. Terdapat beberapa kesamaan ekosistem hutan dengan perkebunan kelapa sawit yang dapat mendukung keanekaragaman laba-laba. Mulai dari kondisi mikrohabitat seperti suhu, kelembaban, 
angin, dan intensitas cahaya yang hampir sama. Serasah yang banyak pada hutan juga ditemukan pada perkebunan kelapa sawit. Perkebunan kelapa sawit banyak ditumbuhi berbagai vegetasi bawah walapun tidak sepadat pada hutan. Budi daya kelapa sawit pada kebun yang terdapat di pinggir hutan jarang tersentuh kegiatan agronomis terutama pengendalian gulma. Kelapa sawit juga menyediakan berbagai mangsa untuk laba-laba predator, bahkan mangsa tersebut adalah hama kelapa sawit. Kondisi ini sebagian besar ditemukan pada kebun yang berjarak $400 \mathrm{~m}$ dari hutan.

Dari 15 famili yang ditemukan terdapat empat spesies laba-laba yang memperlihatkan perubahan spesies dan jumlah individu berdasarkan jarak dari hutan, yakni Araneidae, Lycosidae, Salticidae, dan Tetragnathidae. Berikutnya hanya Famili Lycosidae dan Salticidae yang kembali mengalami peningkatan populasi mulai dari jarak 500 sampai 900 m. Dapat diartikan bahwa Lycosidae dan Salticidae memiliki daya adaptasi yang tinggi terhadap perubahan lingkungan. Populasi akan kembali terbentuk setelah terjadi berbagai gangguan pada habitat, seperti pengendalian gulma, penggunaan insektisida, pengairan, dan replanting.

Argiope sp., H. jugulans, Leucage sp. adalah laba-laba yang melimpah pada jarak $0 \mathrm{~m}$ dari hutan kemudian berkurang drastis pada jarak $100 \mathrm{~m}$, bahkan tidak ditemukan lagi pada jarak 200-400 m dari hutan. Argiope sp. adalah satunya-satunya spesies laba-laba yang memiliki distribusi merata pada beberapa jarak dari hutan. Hal ini cukup menarik karena spesies ini tergolong pembuat jaring yang membutuhkan vegetasi untuk dapat membuat jaring tersebut. Ditambah Argiope sp. dapat membuat jaring pada berbagai tanaman dengan ketinggian yang berbeda, bahkan pada gulma dengan ketinggian $1 \mathrm{~m}$ spesies tersebut tetap dapat membuat jaring. Berbeda dengan Salticidae memiliki keanekaragaman yang rendah pada vegetasi bawah karena hanya hidup dan membuat jaring pada tanaman dengan ketinggian lebih dari $2 \mathrm{~m}$ (Argañaraz et al. 2017). Pada perkebunan kelapa sawit didominasi gulma dengan ketinggian kurang dari $2 \mathrm{~m}$, akan tetapi vegetasi bawah tumbuh merata pada perkebunan kelapa sawit. Kelimpahan laba-laba berkorelasi positif dengan keanekaragaman vegetasi bawah karena menjadi tempat untuk membuat jaring, mempengaruhi ketersediaan mangsa, dan mempengaruhi konsumsi laba-laba oleh burung (Schmidt et al. 2005). Kelapa sawit dengan pelepah panjang yang saling tumpang tindih dapat menjadi sarana untuk Argiope sp. berpindah dari hutan ke semua relung yang terdapat pada perkebunan kelapa sawit.

Perbedaan jumlah individu dan kekayaan spesies pada beberapa jarak dari hutan berpengaruh pada keanekaragaman laba-laba. Hal ini terlihat pada indeks keanekaragaman laba-laba yang tinggi pada jarak $300 \mathrm{~m}$ dari hutan, padahal jumlah individu tertinggi terdapat pada jarak 0 dan $100 \mathrm{~m}$ dari hutan. Pada jarak $300 \mathrm{~m}$ ditemukan labalaba sebanyak 26 spesies dan jumlah tersebut tertinggi dari petak pengamatan yang lain. Secara keseluruhan memang terlihat bahwa semakin jauh dari hutan maka keanekaragaman semakin berkurang. Sebelumnya, hal yang sama sudah dilaporkan Baldissera et al. (2008) bahwa letak geografis hutan dengan perkebunan Araucaria berpengaruh terhadap keanekaragaman laba-laba. Berbeda halnya dengan indeks kemerataan yang hampir sama pada semua jarak dari hutan, yakni $>0,9 \%$ dapat diartikan bahwa pola sebaran labalaba pada beberapa jarak dari hutan adalah merata. Menurut Cornell \& Lawton (1992) bahwa distribusi organisme dapat ditentukan oleh kapasitas dispersi dan kolonisasi, sedangkan banyaknya organisme dalam populasi dapat dipengaruhi interaksi taksa pada skala spasial lokal. Meskipun manipulasi yang dilakukan pada hutan berpotensi memberikan pengaruh buruk, akan tetapi untuk jangka panjang gangguan manusia dapat mempromosikan keanekaragaman karena efek modifikasi habitat oleh manusia sangat tergantung pada tingkat dan frekuensi gangguan.

\section{KESIMPULAN}

Keanekaragaman laba-laba pada perkebunan kelapa sawit berbeda berdasarkan jarak dari hutan. Semakin dekat jarak perkebunan kelapa sawit dari hutan memperlihatkan keanekaragaman yang lebih tinggi mulai dari jarak $100 \mathrm{~m}$ sampai dengan $300 \mathrm{~m}$. Kemerataan spesies laba-laba juga lebih tinggi pada perkebunan kelapa sawit yang dekat 
dengan hutan mulai dari jarak 100 m sampai dengan $300 \mathrm{~m}$.

\section{DAFTAR PUSTAKA}

Argañaraz C, Rubio G, Gleiser R. 2017. Jumping spider (Araneae: Salticidae) diversity in the understory of the Argentinian Atlantic Forest. Ecologia 39:157-168. doi: https://doi. org/10.15446/caldasia.v39n1.60527.

Baldissera R, Ganade G, Brescovit AD, Hartz SM. 2008. Landscape mosaic of Araucaria forest and forest monocultures influencing understorey spider assemblages in southern Brazil. Austral Ecology 33:45-54. doi: https://doi.org/10.1111/ j.1442-9993.2007.01789.x.

Bee L, Oxford G, Smith H. 2017. Britain's Spiders: A Field Guide. Princeton: Princeton University Press.

Bultman TL, Uetz GW. 1982. Abundance and community structure of forest floor spiders following litter manipulation. Oecologia 55:3441. doi: https://doi.org/10.1007/BF00386715.

Cardoso P, Pekár S, Jocqué R, Coddington JA. 2011. Global patterns of guild composition and functional diversity of spiders. Plos One 6:1-10. doi: https://doi.org/10.1371/journal.pone.0021710.

Cornell H, Lawton J. 1992. Species interactions, local and regional processes, and limits to the richness of ecological communities: a theoretical perspective. Journal of Animal Ecology 61:1-12. doi: https://doi.org/10.2307/5503.

Chen K, Tso I. 2004. Spider diversity on Orchid Island, Taiwan: A comparison between habitats receiving different degrees of human disturbance. Zoological Studies 43:598-611.

Chetia P, Kalita DK. 2012. Diversity and distribution of spiders from Gibbon Wildlife Sanctuary, Assam, India. Asian Journal of Conservation Biology 1:5-15.

Costello MJ, Daane KM. 1998. Influence of ground cover on spider populations in a table grape vineyard. Ecological Entomology 23:33-40. doi: https://doi.org/10.1046/j.13652311.1998.00108.x.

Das S, Mahanta N, Kalita J. 2018. Argiope pulchella Thorell, 1881 (Araneidae: Araneae): A potential synanthropic species. International Journal of Zoology Studies 3:265-267.

de Souza ALT, Martins RP. 2004. Distribution of plant-dwelling spiders: Inflorescences versus vegetative branches. Austral Ecology
29:342-349. doi: https://doi.org/10.1111/j.14429993.2004.01371.x.

Downie IS, Abernethy VJ, Foster GN, McCracken DI, Ribera I, Waterhouse A. 1997. Spider biodiversity on Scottish agricultural land. Di dalam: Selden PA (Ed.), Proceedings of the 17th European Colloquium of Arachnology, (Edinburgh 1997. hlm. 311-317. Burnham Beeches: British Arachnological Society.

Elliott F. 1930. An ecological study of the spiders of the Beech-Maple Forest. The Ohio Journal of Science 25:1-22.

Foelix R. 2011. Biology of Spider (3 ${ }^{\text {rd }}$ edition). New York: Oxford University Press (OUP).

Gutierrez DR, Lia M, Scheu S, Drescher J. 2019. A Guide to the Spiders of Jambi (Sumatra, Indonesia) - Identification Version 1.0.

Hill DE, Richman DB. 2009. The evolution of jumping spiders (Araneae: Salticidae ): a review. Peckhamia 75:1-7.

Huseynov EF. 2007. Natural prey of the lynx spider Oxyopes lineatus (Araneae: Oxyopidae). Entomologica Fennica 18:144-148. doi: https:// doi.org/10.33338/ef.84391.

Iida H, Fujisaki K. 2007. Seasonal changes in resource allocation within an individual offspring of the wolf spider, Pardosa pseudoannulata (Araneae: Lycosidae). Physiological Entomology 32:81-86. doi: https://doi.org/10.1111/j.13653032.2006.00545.x.

Karenina T, Herlinda S, Irsan C, Pujiastuti Y. 2019. Abundance and species diversity of predatory arthropods inhabiting rice of refuge habitats and synthetic insecticide application in freshwater swamps in South Sumatra, Indonesia. Biodiversitas 20:2375-2387. doi: https://doi. org/10.13057/biodiv/d200836.

Koh LP, Wilcove DS. 2008. Is oil palm agriculture really destroying tropical biodiversity? Conservation Letters 1:60-64. doi: https://doi. org/10.1111/j.1755-263x.2008.00011.x.

Levi HW. 2002. Keys to the genera of araneid orbweavers (Araneae, Araneae) of the Americas. The Journal of Arachnology 30:527-562. doi: https:// doi.org/10.1636/0161-8202(2002)030[0527:KT TGOA]2.0.CO;2.

Maddison WP. 2015. A phylogenetic classification of jumping spiders (Araneae: Salticidae). The Journal of Arachnology 43:231. doi: https://doi. org/10.1636/arac-43-03-231-292.

Marshall SD, Rypstra AL. 1999. Spider competition in structurally simple ecosystems. The Journal of Arachnology 27:343-350. 
Metzner H. 2018. Jumping spiders (Arachnida: Araneae: Salticidae) of the world. Tersedia pada: https://www.jumping-spiders.com/ [diakses Januari 2020].

Merwe MV, Dippenaar S, Scholtz CH. 1996. Diversity of ground-living spiders at Ngome State Forest, Kwazulu/Natal: A comparative survey in indigenous forest and pine plantations. African Journal of Ecology 34:342-350. doi: https://doi. org/10.1111/j.1365-2028.1996.tb00630.x.

Motta PC, Levi H W. 2009. A new species of Argiope (Araneae: Araneidae) from Brazil. Zoologia 26:334-336. doi: https://doi.org/10.1590/S198446702009000200017.

Öberg S, Mayr S, Dauber J. 2008. Landscape effects on recolonisation patterns of spiders in arable fields. Agriculture, Ecosystems and Environment 123:211-218. doi: https://doi.org/10.1016/j. agee.2007.06.005.

Pirker J, Mosnier A, Kraxner F, Havlík P, Obersteiner M. 2016. What are the limits to oil palm expansion? Global Environmental Change 40:73-81. doi: https://doi.org/10.1016/j. gloenvcha.2016.06.007.

Potapov AM, Dupérré N, Jochum M, Dreczko K, Klarner B, Barnes AD, Krashevska V, Rembold K, Kreft H, Brose U, Widyastuti R, Harms D, Scheu S. 2020. Functional losses in ground spider communities due to habitat structure degradation under tropical land-use change. Ecology 101:14. doi: https://doi.org/10.1002/ecy.2957.

Prószynski J. 2017. Pragmatic classification of the world's Salticidae (Araneae). Ecologica Montenegrina 12:1-133. doi: https://doi. org/10.37828/em.2017.12.1.

Prószyński J. 2016. Delimitation and description of 19 new genera, a subgenus and a species of Salticidae (Araneae) of the world. Ecologica Montenegrina 7:4-32. doi: https://doi. org/10.37828/em.2016.7.1.

Rendón MAP, Ibarra-Núñez G, Parra-Tabla V, García-Ballinas JA, Hénaut Y. 2006. Spider diversity in coffee plantations with different management in southeast Mexico. The Journal of Arachnology 34:104-112. doi: https://doi. org/10.1636/M03-044.1.

Rodrigues, Everton NL, Mendonça M, de S, Rodrigues PES, Ott R. 2015. Diversidade, composição e fenologia de aranhas construtoras de teias (Araneae, Araneidae) associadas com matas ciliares no sul do Brasil. IheringiaSerie Zoologia 105:53-61. doi: https://doi. org/10.1590/1678-4766201510515361.
Rollard C, Wesolowska W. 2002. Jumping spiders (Arachnida, Araneae, Salticidae) from the Nimba Mountains in Guinea. Zoosystema 24:283-307.

Schmidt MH, Roschewitz I, Thies C. 2005. Differential effects of landscape and management on diversity and density of ground-dwelling farmland spiders. Journal of Applied Ecology 42:281-287. doi: https://doi.org/10.1111/j.13652664.2005.01014.x.

Shochat, Stefanov. 2004. Urbanization and spider diversity: Influences of human modification of habitat structure and productivity. Ecological Applications 14:268-280. doi: https://doi. org/10.1890/02-5341.

Sorensen LL. 2004. Composition and diversity of the spider fauna in the canopy of a montane forest in Tanzania. Biodiversity and Conservation, 13:437-452. doi: https://doi.org/10.1023/ B:BIOC.0000006510.49496.1e.

Stenchly K. 2011. Checklist of spiders from Indonesia and New Guinea (Arachnida: Araneae). Di dalam: Data of The World Spider Catalog, Version 11.5 by Norman I. Platnick. Di dalam: http://research. amnh.org/iz/spiders/catalog/INTRO1.html [diakses 3 Januari 2019].

Stiling P, Cornelissen T, Atl B. 2005. What makes a successful biocontrol agent? A meta-analysis of biological control agent performance. Biological Control 34:236-246. doi: https://doi. org/10.1016/j.biocontrol.2005.02.017.

Thomas CFG, Jepson PC. 1997. Field-scale effects of farming practices on linyphiid spider populations in grass and cereals. Entomologia Experimentalis et Applicata 84:59-69. doi: https://doi.org/10.1023/A:1003059815028.

Vijay V, Pimm SL, Jenkins CN, Smith SJ. 2016. The impacts of oil palm on recent deforestation and biodiversity loss. PloS One 11:1-19. doi: https:// doi.org/10.1371/journal.pone.0159668.

Whitmore C, Slotow R, Crouch TE, DippenaarSchoeman AS. 2002. Diversity of spiders (Araneae) in a Savanna Reserve, Northern Province, South Africa. Journal of Arachnology 30:344-356. doi: https://doi.org/10.1636/01618202(2002)030[0344:dosaia]2.0.co;2.

Whyte R, Anderson G. 2017. A Field Guide to Spiders of Australia. Clayton: CSIRO Publishing. doi: https://doi.org/10.1071/9780643107083.

World Spider Catalog. 2019. World spider catalog. Version 19.5. Natural History Museum, Bern. Tersedia pada: http://wsc.nmbe.ch [diakses 3 Januari 2019]. 